\title{
Morphological, developmental and ecological evidence for a progenetic life cycle in Neochasmus (Digenea)
}

\author{
J. Daniel McLaughlin ${ }^{1}$, David J. Marcogliese ${ }^{2}$ and Jocelyn Kelly ${ }^{1,3}$
}

\author{
${ }^{1}$ Department of Biology, Concordia University, 7141 Sherbrooke St. W., Montreal, Quebec H4B 1R6, Canada; \\ ${ }^{2}$ St. Lawrence Centre, Environment Canada, 105 McGill, 7th Floor, Montreal, Quebec H2Y 2E7, Canada; \\ ${ }^{3}$ Current address: Department of Veterinary Biomedical Sciences, University of Saskatchewan, 52 Campus Drive, Saskatoon, \\ Saskatchewan S7N 5B4, Canada
}

Key words: progenesis, life cycle, trematodes, Neochasmus, population biology, metacercaria, fish

\begin{abstract}
Seven species of fishes, Catostomus commersonii (Lacépède), Etheostoma nigrum Rafinesque, Micropterus dolomieu Lacépède, Notemigonus crysoleucas (Mitchill), Notropis hudsonius (Clinton), Perca flavescens (Mitchill), and Percina caprodes (Rafinesque) from the St. Lawrence River, Quebec, Canada, were found infected with progenetic specimens of Neochasmus spp. in the orbits and/or the body musculature. Worms displayed varying degrees of maturation. Eggs occupied the entirety of the worm in late stages of development and persisted as distinct clusters in situ after worm death. Populations of parasites were studied monthly in E. nigrum from one site between May and October in order to follow parasite recruitment, development and maturation. Recruitment of parasites was observed in young-of-the-year fish primarily in July and continued through October. Worms matured rapidly, displaying egg production within a month. Later developmental stages, in which eggs occupied most of the worm, and clusters of eggs became abundant by September. Infections in overwintered fish collected in May consisted mainly of worms in early stages of egg production and of clusters of eggs. When hatched artificially, eggs from the clusters released viable miracidia, indicating that they survive beyond the lifespan of the adult worm. It is suggested that progenesis is a fixed characteristic of the life cycle of these species, that egg dispersal requires the death of the host and that it is facilitated by predation. All prior records of Neochasmus spp. are examined, leading us to conclude that the role of the putative definitive host (primarily basses) has been reduced to that of a dispersal agent. Current hypotheses concerning the evolution and maintenance of progenesis are considered, but it is concluded that they do not apply to this host-parasite system.
\end{abstract}

Life cycles within the Digenea are complex. They typically involve two intermediate hosts and a definitive host; however truncation, or the shortening, of the life cycle from the usual three to two hosts (or even one) is not uncommon and has occurred in at least 32 families (Poulin and Cribb 2002). Phylogenetically, the extent to which truncation occurs varies; it may involve all species within a family, only certain species or, in some cases, only certain members of a particular species (Poulin and Cribb 2002). In many cases truncation involves progenesis where the parasite attains sexual maturity in the second intermediate host.

Members of the family Cryptogonimidae typically require snails and fish as the first and second intermediate hosts, respectively (Yamaguti 1975, Greer and Corkum 1979). Most display the usual three-host life cycle (Yamaguti 1975, Greer and Corkum 1979, 1980) but metacercariae of some species display varying degrees of sexual development (Yamaguti 1975, Hoffman 1999) and those of Aphalloides coelomicola Dollfus, Chabaud et Golvan, 1957 mature in the body cavity of what would normally be the second intermediate host (Maillard 1973, Pampoulie et al. 1999).

Species belonging to Neochasmus Van Cleave et Mueller, 1932 are intestinal parasites of fishes (seven species) and reptiles (one species) (Lamothe-Argumedo et al. 1989, Hoffman 1999). Specimens have also been reported from the body musculature of several species of fishes (e.g. Paperna 1964, Voth and Larson 1968, Noble 1970, Woods 1971, Muzzall and Peebles 1987, Peters in Hoffman 1999, Walker in Hoffman 1999, Carney and Dick 2000). The life cycle of Neochasmus is unknown but, as fish serve as the second intermediate hosts in the life cycles of other cryptogonimids, reports of specimens in the flesh of fish are consistent with a three-host life cycle reported for other members of the family. However, Muzzall and Peebles (1987) observed a range of developmental stages in emerald shiners ( $\mathrm{No}$ tropis atherinoides Rafinesque), and progenetic specimens have also been seen in the muscles by Peters (in Hoffman 1999) and Voth and Larson (1968). We have also found them in several species of fishes collected from various sites in the St. Lawrence River near Montreal, Canada (Marcogliese, unpublished data).

The presence of sexually mature flukes encysted in the muscles of what would normally be the second intermediate host is suggestive of a life cycle that has undergone truncation through the elimination of the normal definitive host. However, the fact that mature specimens of Neochasmus have also been reported from 
the intestine of larger fish suggests that progenetic development in this life cycle may either be facultative (sensu Poulin and Cribb 2002) or that it has not yet evolved to the point where the definitive host has been completely eliminated.

In this study, we report on the prevalence of $\mathrm{NeO}$ chasmus infections in various species of fish collected from sites in the St. Lawrence River near Montreal, Quebec, Canada and then examine the annual infection cycle and age distribution of the parasite in johnny darters (Etheostoma nigrum Rafinesque) from one of those sites to assess the extent of progenesis in the fluke population.

\section{MATERIALS AND METHODS}

Collection of hosts. Sixteen species of fishes were collected at various sites along the St. Lawrence River between Lake St. François and Lake St. Pierre in 1997-99 as part of other ongoing research (Marcogliese and Campagna 1999, Marcogliese et al. 2001) (Fig. 1). All fish were collected with a $22.6 \mathrm{~m} \times 1.5 \mathrm{~m}$ seine fitted with a $3 \mathrm{~mm}$ mesh. Specimens collected in 1997 and 1998 were part of a study on eyeflukes (Diplostomum spp.) and only eyes and orbits were examined. These include 97 golden shiners Notemigonus crysoleucas (Mitchill), 159 spottail shiners Notropis hudsonius (Clinton), 15 young-of-the-year white sucker Catostomus commersonii (Lacépède), 149 young-of-the-year smallmouth bass Micropterus dolomieu Lacépède, 28 logperch Percina caprodes (Rafinesque), 275 yellow perch Perca flavescens (Mitchill) and 72 specimens of E. nigrum. In the following additional samples, whole fish were examined: E. nigrum from Île de la Couvée in September $1998(\mathrm{n}=24)$ and Îles de Boucherville in June $2002(\mathrm{n}=60)$, P. caprodes from Île de la Couvée in September $1998(\mathrm{n}=10)$ and Îlet Vert in July $1999(\mathrm{n}=10)$, and $N$. hudsonius from Îlet Vert $(\mathrm{n}=30)$, Îles de Boucherville $(\mathrm{n}=32)$, Île Beauregard $(\mathrm{n}=30)$ and Île St. Ours $(\mathrm{n}=32)$ in August-September 1999) (Fig. 1). In order to follow the seasonal progression of infection and the development and maturation of the flukes in fish, specimens of E. nigrum were collected from Île Deslauriers (Fig. 1) in May $(\mathrm{n}=50)$, June $(\mathrm{n}=$ $49)$, July $(\mathrm{n}=41)$, September $(\mathrm{n}=62)$ and October $(\mathrm{n}=56)$ 2001. The entire fish was examined in these samples. Mean abundance and intensity values are given as the mean \pm 1 SD. Prevalence is expressed as a percent. For those fish where only eyes and orbits were examined, the prevalence was calculated for each host species by combining all specimens from the various sites on an annual basis. These values will clearly underestimate true prevalence.

Collection of parasites. Fish were transported live to the laboratory and maintained at $15-19^{\circ} \mathrm{C}$ for a maximum of two weeks prior to examination. The fish were killed in MS 222 and the total length of each fish was measured to the nearest $\mathrm{mm}$. To minimize effects from multiple age classes, only fish $\leq 50 \mathrm{~mm}$ in total length were used to interpret seasonal patterns. The eyes were removed and their external surface was examined, under magnification, for parasites. Then the orbits were examined and finally, the fish was skinned and the musculature was examined using transmitted light and a stereomicroscope. Flukes were found in cysts on the orbital surface of

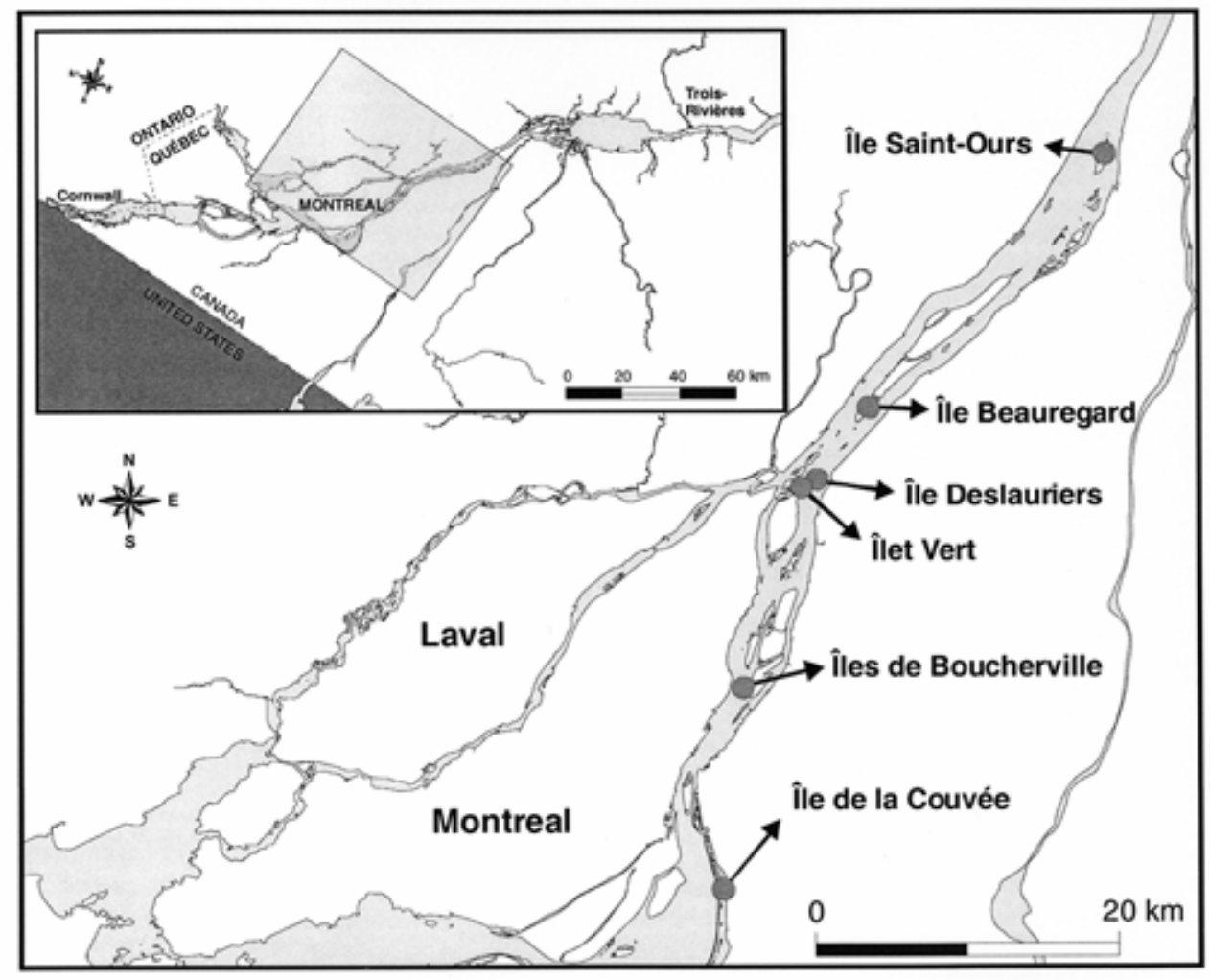

Fig. 1. Map of the St. Lawrence River, Quebec, Canada, with sampling localities. Inset: The location of the St. Lawrence River in eastern North America. 
the eye and within the musculature. These were dissected free of the tissues, placed in water and opened with dissecting needles to release the parasites. Most of the flukes were fixed in hot $70 \%$ ethanol but a small sample was fixed in absolute ethanol for eventual DNA extraction and sequencing. Specimens prepared as whole mounts were stained in acetocarmine. For most flukes, the anterior end was removed and mounted en face to facilitate the counting and measurement of the oral spines. We also found what proved to be the eggs of the encysted flukes that appeared as small light to dark brown masses in the muscles (hereafter referred to as egg clusters). These were dissected free of the tissues and examined microscopically as temporary mounts to verify the presence of eggs. Several $5 \mathrm{~mm}$ long sections of fish containing encysted flukes or egg clusters were placed in Bouin's fixative for histological study. Paraffin sections were cut at $8 \mu \mathrm{m}$ and stained in Mayer's haematoxylin and eosin for microscopical examination.

Flukes used in the seasonal study were classified into three developmental stages based on the presence and volume of eggs in the uterus. We used the original drawing of Neochasmus umbellus Van Cleave et Mueller, 1932 as the standard and each specimen was placed in one of the following categories: juveniles and young flukes without eggs (stage 1), those with the uterus $1 / 4-1 / 2$ full of eggs (stage 2 ), those with the uterus over $1 / 2$ to completely full of eggs (stage 3 ). Egg clusters were placed in a separate category (stage 4). The proportion of stages in each developmental category was determined from all worms pooled together in each fish sample.

Sixteen flukes (5 in stage 2 and 11 in stage 3 ) and eight egg clusters from E. nigrum collected at Îles de Boucherville (June 2002) and Îlet Vert (June 2004) were placed in aged tap water for 48-96 hours. Individual flukes and egg clusters were placed in a drop of water on a slide, and a cover glass was added. Forceps were used to apply sufficient pressure to rupture the eggs (Greer and Corkum 1979) which were then examined under low power magnification for miracidia.

\section{RESULTS}

\section{General observations}

Two species of Neochasmus were found in this study. Six specimens with 27 oral spines were found in preliminary studies. These were identified as $N$. umbellus. All of the other specimens examined in detail (ca. 250) appear to belong to an undescribed species. They resemble $N$. umbellus in general morphology but possess 31-37 oral spines rather than 27. As the overwhelming majority of specimens belong to the latter species the data were pooled and analysed as though it represented a single species and reported here as Neochasmus sp.

The mature flukes were found in cysts that measured roughly $240-280$ by $250-440 \mu \mathrm{m}$ in situ. Each thinwalled, transparent cyst contained a single fluke $(>1,000$ observations) that was readily visible within it. Some cysts were located on the external surface of the eye within the orbit but most were found in the head and body musculature. There was little or no evidence of a host reaction in the musculature around the cyst (Fig. 2).
Miracidia were visible within the eggs of sectioned specimens. No cysts were found in the body cavity or in the visceral organs.

Most worms encountered displayed some degree of maturation. The number of eggs present in the specimens varied and one fluke found late in the study was virtually packed with eggs. Clusters of fluke eggs, each representing the lifetime egg production of an individual fluke, were present in the muscles of many fish (Fig. 3). The eggs were identical to those in the adult flukes and fluke structures, including the oral sucker and oral spines, were visible in some sections. Unlike the flukes, the egg clusters did not appear to be sequestered from host tissue. The egg cluster and, occasionally, the area immediately around it was infiltrated by granular cells. The clusters could usually be removed intact from the surrounding tissue.

Eggs from 5 stage- 2 flukes, 9 of 10 stage- 3 flukes and 7 of 8 egg clusters released miracidia when ruptured. For all but 2, a minimum of 30 miracidia were counted on each slide. These died quickly in water. Activity declined steadily in the first 5 minutes and in most cases, movement had ceased within 10 minutes after the miracidia were released from the eggs.

\section{Preliminary survey studies}

Encysted specimens of Neochasmus spp. were found in the eyes and orbits of 7 species collected at sites in the St. Lawrence River in 1997-98, including N. hudsonius, $N$. crysoleucas, $P$. caprodes, $P$. flavescens, and $E$. nigrum, and in young-of-the-year of $M$. dolomieu and $C$. commersonii. Total prevalence was highest for $E$. nigrum (26\%) and $P$. caprodes $(14 \%)$, but was $<7 \%$ for the other species.

Prevalence was markedly higher in samples of fish in which the musculature was also examined. In the sample of E. nigrum collected from Île de la Couvée in September 1998, prevalence of infection with Neochasmus spp. was $54 \%$. Flukes were not counted in this sample. In those collected from Îles de Boucherville in June 2002 , the prevalence was $45 \%$, the mean abundance 0.8 \pm 1.18 and the mean intensity $1.78 \pm 1.15$. For $P$. caprodes collected from Île de la Couvée in September 1998 , prevalence was $60 \%$ and mean abundance $1.7 \pm$ 1.9. For those from Îlet Vert collected in July 1999, prevalence and mean abundance were $50 \%$ and $0.9 \pm$ 1.1, respectively. Among N. hudsonius collected from four sites in August-September 1999, prevalence ranged from 10.0 to $36.7 \%$, mean abundance from 0.23 \pm 0.94 to $0.67 \pm 1.37$, and mean intensity from $1.14 \pm$ 0.38 to $2.33 \pm 2.31$, except at Îles de Boucherville, where none of the fish examined were infected.

\section{Seasonal studies}

Specimens of E. nigrum examined for seasonal trends in development of Neochasmus spp. in May and June were larger than those collected in July (Fig. 4). Large fish collected earlier in the spring and in smaller 


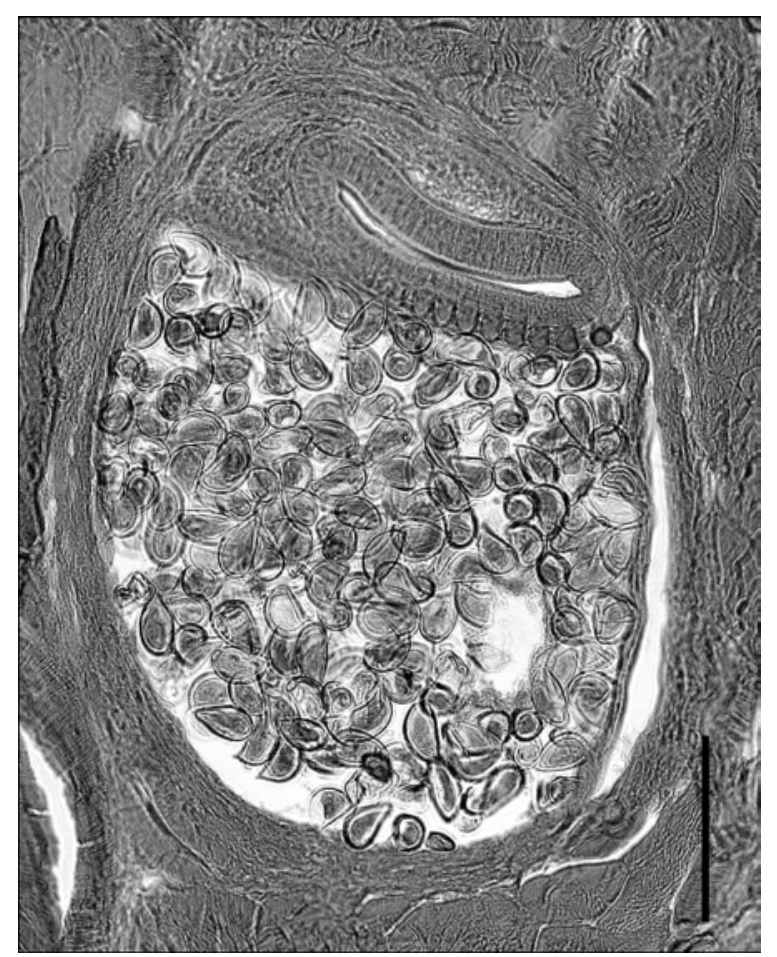

Fig. 2. Histological section of an adult specimen of Neochasmus sp. in the body musculature of Etheostoma nigrum. Note the oral spines visible along the oral sucker. Scale bar $=100$ $\mu \mathrm{m}$.

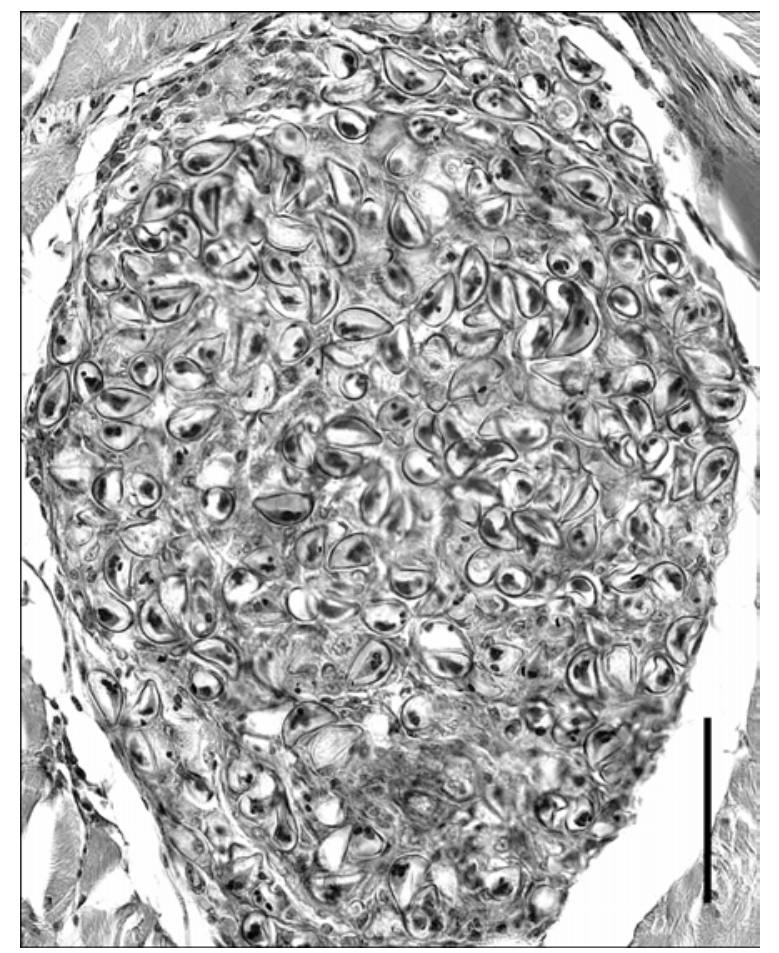

Fig. 3. Histological section of an egg cluster of Neochasmus $\mathrm{sp}$. in the body musculature of Etheostoma nigrum. Note the characteristic eggs and the presence of miracidia within them. Scale bar $=100 \mu \mathrm{m}$.

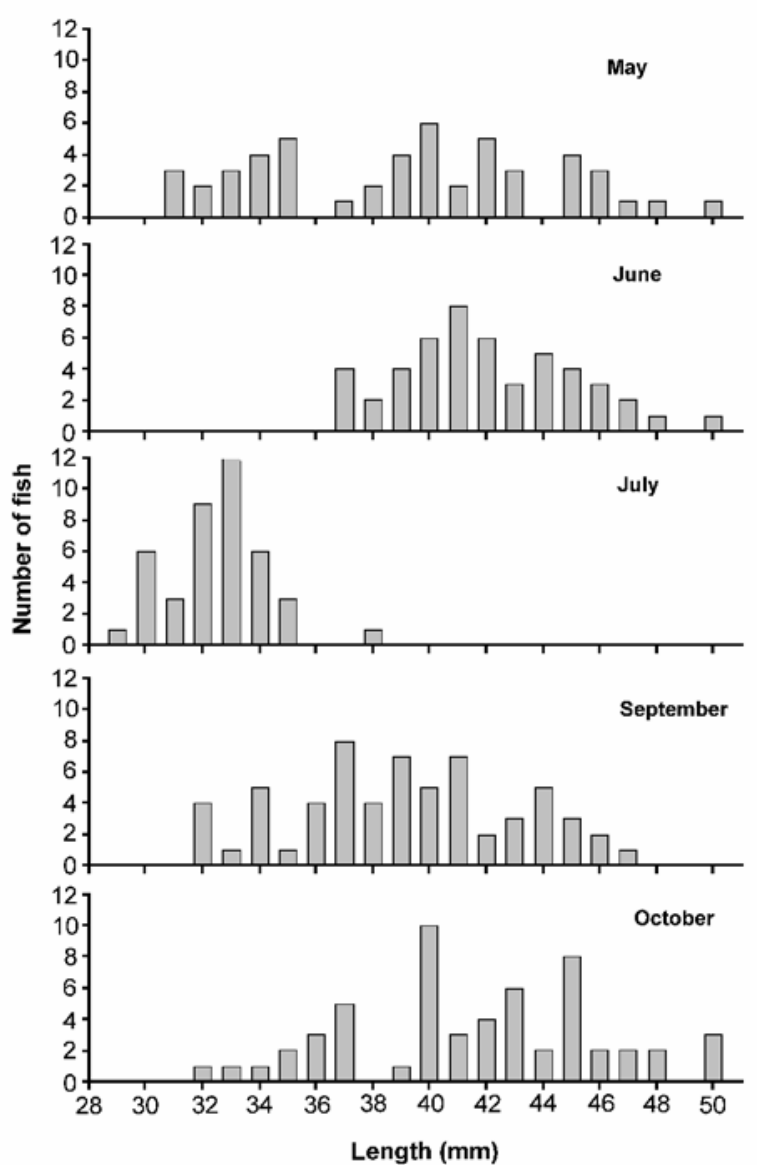

Fig. 4. Length frequency distribution of Etheostoma nigrum collected from Île Deslauriers, St. Lawrence River, Quebec in 2001.

numbers throughout the summer were considered to have overwintered. Smaller fish that appeared in the July sample were considered to be young-of-the-year $(0+)$ and this cohort was followed through October. The size-frequency distribution suggested that recruitment to the fish population continued at least through late summer (Fig. 4).

Prevalence of the three worm stages increased slightly over time from $44.0 \%$ in May to a maximum of $58 \%$ in September. Prevalence of all developmental stages, that is, worm stages plus egg clusters, was $56 \%$ and $78 \%$ in May and June respectively in overwintered fish, and fluctuated between $56 \%$ and $66 \%$ in young-ofthe-year fish during the rest of the summer and fall.

The proportion of developmental stages displayed a distinct seasonal pattern. In the spring, most worms were either at stage $2(42 \%)$ or had died and disintegrated producing egg clusters (38\%) (stage 4). As there was no evidence of recruitment to the fluke population in these fish (Fig. 5), the data suggest that the parasites overwintered in the fish host. Between May and June, the proportion of worms at stage 2 decreased from 42 to $25 \%$, whereas the proportion of egg clusters (stage 4 ) 


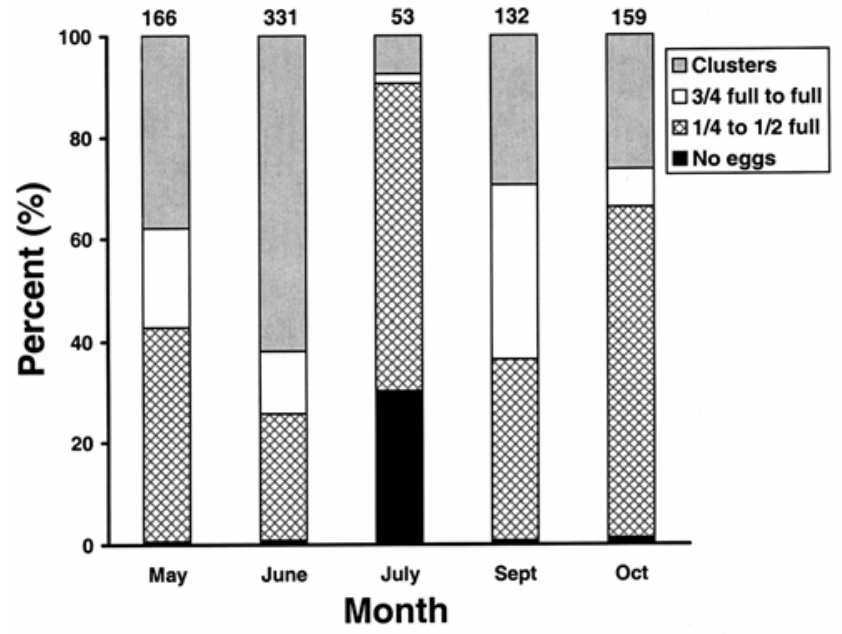

Fig. 5. Relative occurrence, expressed as a percent, of developmental stages of Neochasmus spp. in samples of Etheostoma nigrum collected from Île Deslauriers, St. Lawrence River, Quebec in 2001. Sample sizes are indicated above each histogram.

increased from 38 to $62 \%$, suggesting maturation of overwintered individuals. In July, in a sample dominated by young-of-the-year fish (Fig. 4), there was evidence of recruitment, as worms without eggs (stage 1) were common (Fig. 5). In fact, most worms in the July sample were at stage $1(30 \%)$ or $2(60 \%)$, suggesting recent recruitment and relatively rapid sexual development. A few egg clusters were also seen in this sample. In September, the proportion of flukes in stage 3 and egg clusters (stage 4 ) increased to $64 \%$, suggesting further maturation of worms. In October, a small percentage $(1 \%)$ of worms had no eggs. The majority $(65 \%)$ of worms were in stage 2, again suggesting a short maturation time (Fig. 5). The distribution of stages in the October sample was similar to that seen in sample from the previous May further suggesting that the majority of the parasites persist over winter in stage 2 or as egg clusters.

\section{DISCUSSION}

Two species of Neochasmus were found in this study. Six specimens of $N$. umbellus were found in the preliminary study but none were found thereafter. Most of the specimens belonged to a second species characterized by a row of 31-37 oral spines 20-26 $\mu \mathrm{m}$ long. These specimens resembled Neochasmus sogandaresi Overstreet, 1971 in the number and size of the oral spines but resembled $N$. umbellus more closely in general morphology. They are identified here as Neochasmus sp. pending further study. For purposes of this study, all specimens are treated as a single species.

Preliminary studies, based only on examination of the eyes and orbits, revealed infections in 7 of 16 species of fishes collected near Montreal (see Marcogliese and Compagna 1999 for complete list) bringing to 10 the number of species reported with infections in either the eyes or the musculature (Table 1). The most common hosts were various species of Etheostoma and Notropis, but other species, including certain species of piscivorous fishes, were also infected. The prevalence of Neochasmus was higher (10-78\%) in samples where the whole body was examined than in the preliminary study, but it was comparable to that reported elsewhere (Table 1, but see Noble 1970). Many infections went undetected in the preliminary study and both the infection levels within each species and the distribution of the parasite within the fish community are clearly underestimated.

Only two species of fishes examined in this study have been examined elsewhere. The prevalence of Neochasmus observed in various samples of Etheostoma nigrum in our study (45\% to $78 \%$ ) was comparable to that reported by Voth and Larson (1968) and by Woods (1971) (Table 1) however, the prevalence in Perca flavescens reported by Carney and Dick (2000) was much higher. This is due partly to the fact that our observations were limited to the eyes and orbits of young-ofthe-year and 1+ cohorts whereas Carney and Dick (2000) examined the entire fish and their sample included older fish. Intensity data are scarce but, in studies where they are available, the mean intensity ranged from 2.6 to 12.8 flukes in P. flavescens and Notropis atherinoides (Carney and Dick 2000, Muzzall and Peebles 1987, respectively). This is higher than that found in E. nigrum, Percina caprodes and Notropis hudsonius, the only species for which we collected such data.

The parasite fauna of freshwater fishes has been studied extensively in Canada and the United States. Despite the high prevalence infection in what should be the second intermediate host however, reports of Neochasmus infections in the intestine of larger fish, presumed to be definitive hosts, are rare. Three species, N. umbellus, $N$. sogandaresi (1 record) and $N$. ictaluri SogandaresBernal, 1955 (2 records), have been reported from fishes in the United States (Hoffman 1999); only N. umbellus has been reported from Canada (Margolis and Arthur 1979, McDonald and Margolis 1995). Many of the studies involved large sample sizes and several species of fishes but only 62 fish (6 species), of which 38 were white bass Morone chrysops (Rafinesque), have been found with intestinal infections of $N$. umbellus (Table 2). Data from the study on Micropterus dolomieu (Anthony 1985; no quantitative data available) are excluded. The limited intensity data indicates that infections typically involve small numbers of flukes and only 1 fish has been reported with an infection exceeding 10 flukes (Bangham and Hunter 1939).

The seasonal data from E. nigrum provided several insights into the developmental cycle of Neochasmus Firstly, the proportion of young flukes (stages 1 and 2) 
Table 1. Summary of previous records of Neochasmus umbellus and Neochasmus sp. from the eyes and musculature of fishes in North America. Most authors identified their specimens as Neochasmus sp. Hoffman (1967) reported infections in Fundulus diaphanus (Lesueur) but no further data were provided. Data from hosts collected from different geographical locations or years are presented separately. Prevalence data were rounded to next whole number. M - musculature, E - external surface of the eye, $\mathrm{G}-$ gills.

\begin{tabular}{|c|c|c|c|c|c|}
\hline Host species & Reference & Site & $\mathrm{n}$ & Prevalence & Infection details \\
\hline Etheostoma nigrum & Voth and Larson 1968 & $\mathrm{M}$ & 13 & 85 & $\begin{array}{l}11 \text { fish infected; } \\
\text { progenetic specimens }\end{array}$ \\
\hline Etheostoma nigrum & Woods 1971 & $\mathrm{M}^{1}$ & 17 & 53 & 9 fish infected \\
\hline Notropis atherinoides & Muzzall and Peebles 1987 & $\begin{array}{l}\mathrm{E} / \mathrm{M} / \mathrm{G} \\
\mathrm{E} / \mathrm{M} / \mathrm{G}\end{array}$ & $\begin{array}{l}100 \\
100\end{array}$ & $\begin{array}{l}84 \\
70\end{array}$ & $\begin{array}{l}84 \text { fish infected } \\
70 \text { fish infected }\end{array}$ \\
\hline Notropis atherinoides & Walker in Hoffman 1999 & $\mathrm{M}$ & - & - & $\begin{array}{l}\text { no data; } \\
\text { progenetic specimens }\end{array}$ \\
\hline Perca flavescens & Noble 1970 & $E^{2}$ & 54 & 2 & 1 fish infected \\
\hline Perca flavescens & Carney and Dick 2000 & $\begin{array}{l}\mathrm{M}^{3} \\
\mathrm{M}^{3}\end{array}$ & $\begin{array}{c}63 \\
102\end{array}$ & 25 & $\begin{array}{l}21 \text { fish infected } \\
25 \text { fish infected }\end{array}$ \\
\hline Percina maculata (Girard) & Woods 1971 & $\mathrm{M}^{1}$ & 10 & 60 & 6 fish infected \\
\hline Unidentified fish & Peters in Hoffman 1999 & $\mathrm{M}$ & - & - & $\begin{array}{l}\text { no data; } \\
\text { progenetic specimens }\end{array}$ \\
\hline
\end{tabular}

${ }^{1}$ Author indicated specimens were metacercariae but did not give site.

${ }^{2}$ Identified only to family level; thought to be a species of Neochasmus or Allocanthochasmus.

${ }^{3}$ Back calculated from original prevalence data; number of infected fish rounded to next lowest whole number.

Table 2. Summary of records of Neochasmus umbellus from the digestive tract of fishes in North America. Hoffman (1967) reported infections in Fundulus diaphanus but no further data were provided. Van Cleave and Muller (1934) reported one sexually mature fluke from the intestine of Necturus maculosus (Amphibia). Prevalence data were rounded to next whole number. Data from hosts collected from different geographical locations or years are presented separately.

\begin{tabular}{|c|c|c|c|c|}
\hline Host species & Reference & $\mathrm{n}$ & Prevalence & Infection details \\
\hline $\begin{array}{l}\text { Etheostoma microperca } \\
\text { Jordan et Gilbert }\end{array}$ & Bangham and Venard 1942 & 15 & $20^{1}$ & 3 fish infected \\
\hline Etheostoma olmstedi Storer & Van Cleave and Mueller 1934 & 25 & 4 & 1 fish infected; 2 flukes \\
\hline Micropterus dolomieu & Dechtiar 1972 & 37 & 6 & 2 fish infected; $<10$ flukes \\
\hline Micropterus dolomieu & Bangham and Hunter 1939 & 48 & $7^{2}$ & $\begin{array}{l}3 \text { fish infected; } 2 \text { with } 1-9 \text { flukes, } \\
1 \text { with } 10-49 \text { flukes }\end{array}$ \\
\hline Micropterus dolomieu & Anthony 1985 & $?$ & no data ${ }^{3}$ & low infection levels \\
\hline $\begin{array}{l}\text { Micropterus salmoides } \\
\text { (Lacépède) }\end{array}$ & Van Cleave and Mueller 1934 & 44 & 3 & 1 fish infected; 7 flukes \\
\hline Morone chrysops & Dechtiar and Christie 1988 & 15 & 34 & 5 fish infected \\
\hline Morone chrysops & Dechtiar and Nepszy 1988 & 133 & 24 & 18 fish infected \\
\hline Morone chrysops & Forstie and Holloway 1984 & 11 & 64 & 7 fish infected \\
\hline $\begin{array}{l}\text { Morone mississippiensis } \\
\text { Jordan et Eigenmann }\end{array}$ & McReynolds and Webster 1980 & $\begin{array}{l}49 \\
13\end{array}$ & $\begin{array}{l}12 \\
23\end{array}$ & $\begin{array}{l}6 \text { fish infected } \\
3 \text { fish infected }\end{array}$ \\
\hline
\end{tabular}

${ }^{1}$ Authors did not state site explicitly; specimens were mature and in context from the intestine.

${ }^{2}$ Authors classified intensities by range.

${ }^{3}$ Author did not specify site; but metacercariae were identified as such so it is assumed that these specimens were from the intestine. Frequencies and infection were reported overall as "low to moderate" no further details provided for N. umbellus.

in young-of-the-year fish indicates that the major recruitment period occurs in early summer and continues, at reduced levels, into autumn. Secondly, the flukes can overwinter in the host. Thirdly, the metacercariae develop directly into sexually mature flukes. This observation is consistent with the range of developmental stages reported in the muscles of $N$. atherinoides by Muzzall and Peebles (1987) and with other reports of progenetic specimens in fish (Voth and Larson 1968, Peters in Hoffman 1999). Fourthly, sexual maturation occurs rap- idly and eggs are present in the uterus of specimens obtained from young-of-the-year fish in July. This contrasts with most previous reports where progenesis occurs in ageing metacercariae in the intermediate host (see Poulin and Cribb 2002). The large proportion of sexually mature flukes found in this study provides strong support for the hypothesis that progenetic development is a fixed characteristic in the life cycle, at least in the species of Neochasmus found in southwestern Quebec. Finally, the accumulation of egg clusters in the 
muscles of young-of-the-year fish indicates that the life span of encysted flukes is much shorter than that of the host although the eggs remain viable in the host tissue for an undetermined period of time. Although varying degrees of development have been reported in the reproductive systems of the metacercariae in a number of cryptogonimid species (Yamaguti 1975, Greer and Corkum 1979), all except Aphalloides coelomica appear to have retained a three-host life cycle. The latter species lives in the coelom of the common goby, Pomatoschistus microps (Krøyer) where it produces clusters of eggs, enclosed in an envelope of presumed parasite origin (Pampoulie et al. 2000). Neochasmus represents a second example of progenesis within the family and is the first to produce accumulations of eggs in the musculature fish.

Truncation of the life cycle and progenetic development implies a fitness benefit over the typical three-host cycle, but the selective pressures that may have lead to this developmental pattern are unclear. Poulin and Cribb (2002) reviewed five hypotheses, none of which are mutually exclusive, that attempt to account for progenetic development and shortening of the life cycle in digeneans; however, none of these appear to apply to Neochasmus. First, the habitat used by fish in our study is neither unstable nor unpredictable (environmental instability hypothesis). Second, cannibalism (sensu Poulin and Cribb) does not appear play a role in transmission beyond the occasional ingestion of a smaller conspecific (cannibalism hypothesis). Third, although the only reports of progenetic specimens have been from the northern United States and southern Canada, these sites experience a temperate climate and the transmission window is not restricted as in polar climates (latitudinal hypothesis). Five species of Neochasmus are known from the southern United States, Mexico and Venezuela and comparable studies would be of interest as a further test of this hypothesis and in assessing the extent to which progenesis occurs among species of Neochasmus. Fourth, the diversity of fish species reported in the larger surveys demonstrates that known definitive hosts are plentiful although their abundance may vary locally (Lee et al. 1980, Bernatchez and Giroux 2000) (missing host hypothesis). Fifth, despite exceptions, facultative progenesis usually occurs in ageing, long-lived, metacercariae or within ageing intermediate hosts ensuring that a limited number of eggs are available for dispersal by predation or natural death in the event that transmission to the definitive host does not occur (developmental time hypothesis). The situation in Neochasmus is just the reverse and is characterized by rapid sexual development and the production of a large number of eggs that can survive in the host long after the parent worm has died.

Egg dispersal rather than egg production is the major reproductive challenge for encysted flukes such as Neochasmus. Dispersal depends upon the death and disinte- gration of the host (Poulin and Cribb 2002) which can be accomplished through predation or through natural causes. Such is the case for A. coelomica (Maillard 1973, Pampoulie et al. 1999, 2000). A situation more similar to ours involves Lecithochirium furcobilabiatum (Jones, 1933), which matures in the body cavity of several species of rock pool fishes but has also been reported from the intestine of eels (Gibson and Bray 1986). In neither case is the definitive host necessary for maturation, yet it persists. The role of the presumptive definitive host in the life cycle of such flukes is unclear and may differ among species. If a functional definitive host persists in the life cycle it would provide an opportunity for cross-fertilisation which is not possible for Neochasmus encysted in the musculature. Alternatively, it may be reduced to a dispersal agent for the eggs. The first option is unlikely because a definitive host is not required for sexual maturation or egg production. If establishment in the intestine were to prolong the life span and increase egg production, dispersal could be extended in space and time. However, we are unaware of any study that demonstrates conclusively that egg production in progenetic flukes increases in the event they gain access to a suitable definitive host. Hence, there would appear to be little selective pressure for these hosts to persist as obligate components of the parasite's life cycle. Alternatively, the flukes either do not survive in the intestine or survive only briefly, thereby limiting the role of the host to that of a dispersal agent. Two lines of evidence lend support to this hypothesis in the case of Neochasmus. First, rapid death and/or elimination of the flukes would greatly reduce the chances of their being found in surveys and could well account for the low prevalence and intensity observed in intestinal infections of larger fish. Second, if predation is the primary means of egg dispersal, selection should favour progenetic individuals that produce large numbers of eggs rapidly rather than a small number as a last resort at the end of their life span. Rapid production of eggs would be adaptive because it would ensure that eggs are available for dispersal whenever the host dies. Up to 200 eggs are already present in stage-2 flukes and at least 3-4 times as many are present in stage-3 flukes (unpublished data).

The limitations of the apparently short individual life span are partially met in two ways. Recruitment is continuous throughout the summer and early autumn providing a continuous, albeit temporally variable replacement of dead flukes, and the eggs of dead flukes remain viable long after the parent worm has died. Eggs from clusters found in older fish that had overwintered released miracidia when hatched artificially. Recruitment of these infections would have occurred in late summer or autumn of the previous year indicating that they remain viable for several months.

The available data suggest that the levels of infection in Etheostoma, Notropis, Perca and other fishes should 
be sufficient to sustain a typical three-host life cycle and potential definitive hosts are likely exposed on a regular basis. Definitive hosts do become infected but the infections appear transitory probably due to the inability of the parasites to survive for long in the intestine of the host. In terms of complex life cycles, predation is generally viewed in the context of transmission from one host to the next, yet other examples exist (e.g. the didymozoid Halversonius exilis Gibson, MacKenzie et Cottle, 1981 and the nematode Calodium hepatica (Bancroft, 1893) (Gibson et al. 1981, Anderson 2000, respectively) where decomposition or predation are the only mechanisms for the dispersal of eggs from host tissues. In the absence of experimental data to the contrary, the use of larger fish and perhaps or other predators as dispersal agents appears to be the most parsimonious ex- planation of the transmission strategy of this parasite and may explain unusual infections reported in Necturus (Amphibia) and Nerodia (Reptilia) (Van Cleave and Mueller 1934, Bennett 1935, respectively).

Acknowledgements. This work was supported by Natural Sciences and Engineering Council of Canada Discovery grant A6979 to J.D. McLaughlin. Jocelyn Kelly was the recipient of a Natural Sciences and Engineering Council of Canada Summer Fellowship. We thank Dr. Igor Mikaelian for his examination and evaluation on the histopathology associated with the parasite. Field and technical assistance was provided by Michel Arseneau, Stephanie Barbeau, François Boudreault, Germain Brault, Annie Ciarlo, Sacha Compagna, Katia Étienne, Tara Gariepy, Andrée Gendron, Meaghan Hunter, Sean Locke, Karen $\mathrm{Ng}$ and Céline Plante.

\section{REFERENCES}

ANDERSON R.C. 2000: Nematode Parasites of Vertebrates Their Development and Transmission. Second edition. CAB International, Wallingford, UK, $650 \mathrm{pp}$.

ANTHONY D.D. 1985: Helminth parasites of centrarchids from Lake Nipissing, Ontario. $60^{\text {th }}$ Annual Meeting, American Society of Parasitologists, Athens, Georgia, Program and Abstracts, Abstract 50A.

BANGHAM R.V., HUNTER G.W. III. 1939: Studies on fish parasites of Lake Erie. Distribution studies. Zoologica (N.Y.) 24: 385-448.

BANGHAM R.V., VENARD C.E. 1942: Studies of parasites of Reelfoot Lake fish. IV. Distribution studies and checklist of parasites. J. Tenn. Acad. Sci. 17: 22-38.

BENNETT H.J. 1935: Four new trematodes from reptiles. J. Parasitol. 21: 83-90 + 2 pl.

BERNATCHEZ L., GIROUX M. 2000: Les Poissons d'Eau Douce du Québec et leur Répartition dans l'Est du Canada. Broquet, Boucherville, Quebec, 350 pp.

CARNEY J.P., DICK T.A. 2000: Helminth communities of yellow perch (Perca flavescens (Mitchill)): determinants of pattern. Can. J. Zool. 78: 538-555.

DECHTIAR A.O. 1972: Parasites of fish from Lake of the Woods, Ontario. J. Fish. Res. Board Can. 29: 275-283.

DECHTIAR A.O., CHRISTIE W.J. 1988: Survey of the parasite fauna of Lake Ontario fishes, 1961-1971. In: S.J. Nepszy (Ed.), Parasites of fishes in the Canadian waters of the Great Lakes. Great Lakes Fishery Commission Technical Report 51, pp. 66-95.

DECHTIAR A.O., NEPSZY S.J. 1988: Survey of the parasite fauna of selected fish species from Lake Erie. In: S.J. Nepszy (Ed.), Parasites of fishes in the Canadian waters of the Great Lakes. Great Lakes Fishery Commission Technical Report 51, pp. 49-65.

FORSTIE M.D., HOLLOWAY H.H. 1984: Parasites of fish from the James and Sheyenne Rivers, Jamestown reservoir complex, and Lake Ashtabula in North Dakota. Prairie Nat. 16: 11-20.

GIBSON D.I., BRAY R.A. 1986: The Hemiuridae (Digenea) of fishes from the north-east Atlantic. Bull. Br. Mus. Nat. Hist., Zool. 51: 1-125.
GIBSON D.I., MacKENZIE K.M., COTTLE J. 1981: Halvorsonius exilis gen. et sp. nov., a new didymozoid trematode from the mackerel Scomber scombrus L. J. Nat. Hist. 15: 917-920.

GREER G.J., CORKUM K.C. 1979: Life cycle studies of three digenetic trematodes, including descriptions of two new species (Digenea: Cryptogonimidae). Proc. Helminthol. Soc. Wash. 46: 188-200.

GREER G.J., CORKUM K.C. 1980: Notes on the biology of three trematodes (Digenea: Cryptogonimidae). Proc. Helminthol. Soc. Wash. 47: 47-51.

HOFFMAN G.L. 1967: Parasites of North American Freshwater Fishes. University of California Press, Berkeley, California, $486 \mathrm{pp}$.

HOFFMAN G.L. 1999: Parasites of North American Freshwater Fishes. Second Edition. Comstock Publishing Associates, Ithaca, New York, $539 \mathrm{pp}$.

LAMOTHE-ARGUMEDO R., PINEDA-LÓPEZ R., SALAS O.A. 1989: Descripcion de una especie nueva del genero Neochasmus (Trematoda: Cryptogonimidae) parasita de peces de Tabasco, Mexico. Univ. Cienc. 6: 11-14.

LEE D.S., GILBERT C.R., HOCUTT C.H., JENKIND R.E., McALLISTER D.E., STAUFFER J.R. Jr. 1980: Atlas of North American Freshwater Fishes. North Carolina Biological Survey No. 1980-12, North Carolina State Museum of Natural History, Raleigh, North Carolina, 867 pp.

MAILLARD C. 1973: Mise en évidence du cycle évolutif abrégé d'Aphalloïdes coelomica Dollfus, Chabaud et Golvan, 1957 (Trematoda). Notion d'hôte historique. C. R. Acad. Sci. Paris 277D: 317-320.

MARCOGLIESE D.J., COMPAGNA S. 1999: Diplostomatid eye flukes in young-of-the-year and forage fishes in the St. Lawrence River, Quebec. J. Aquat. Anim. Health 11: 275282.

MARCOGLIESE D.J., COMPAGNA S., BERGERON E., McLAUGHLIN J.D. 2001: Population biology of eyeflukes in fish from a large fluvial ecosystem: the importance of gulls and habitat characteristics. Can. J. Zool. 79: $1102-1113$. 
MARGOLIS L., ARTHUR J.R. 1979: Synopsis of the parasites of fishes of Canada. Fisheries Research Board of Canada Bulletin No. 199. Department of Fisheries and Oceans, Ottawa, Canada, 269 pp.

McDONALD T.T., MARGOLIS L. 1995: Synopsis of the parasites of fishes of Canada: supplement (1978-1993). Canadian Special Publication of Fisheries and Aquatic Sciences No. 122. National Research Council of Canada, Ottawa, Canada, 265 pp.

McREYNOLDS M., WEBSTER J.D. 1980: Parasites of the yellow bass from two southern Indiana lakes. Proc. Indiana Acad. Sci. 89: 154-158.

MUZZALL P.M., PEEBLES R.C. 1987: Parasites of the emerald shiner, Notropis atherinoides, from two localities in the St. Mary's River, Michigan, with emphasis on larval trematodes. Proc. Helminthol. Soc. Wash. 54: 105-110.

NOBLE R.L. 1970: Parasites of yellow perch in Oneida Lake, New York. N.Y. Fish Game J. 17: 95-101.

PAMPOULIE C., MORAND S., LAMBERT A., ROSECCHI E., BOUCHEREAU J.L., CRIVELLI A.J. 1999: Influence of the trematode Aphalloides coelomicola Dollfus, Chabaud \& Golvan, 1957 on the fecundity and survival of Pomatoschistus microps (Krøyer, 1838) (Teleostei: Gobiidae). Parasitology 119: 61-67.
PAMPOULIE C., LAMBERT A., ROSECCHI E., CRIVELLI A.J., BOUCHEREAU J.L., MORAND S. 2000: Host death: a necessary condition for the transmission of Aphalloïdes coelomicola Dollfus, Chabaud \& Golvan, 1957 (Digenea: Cryptogonimidae)? J. Parasitol. 86: 416-417.

PAPERNA I. 1964: The metazoan parasite fauna of Israel inland-water fishes. Bamidgeh 16: 1-66.

POULIN R., CRIBB T.H. 2002: Trematode life cycles: short is sweet? Parasitol. Today 18: 176-183.

VAN CLEAVE H.J., MUELLER J.F. 1932: Parasites of Oneida Lake fishes. Part I. Descriptions of new genera and new species. Roosevelt Wild Life Ann. 3: 5-71.

VAN CLEAVE H.J., MUELLER J.F. 1934: Parasites of Oneida Lake fishes. Part III. A biological and ecological survey of the worm parasites. Roosevelt Wild Life Ann. 3: 161-334.

VOTH D.R., LARSON O.R. 1968: Metazoan parasites of some fishes from Goose River, North Dakota. Am. Midl. Nat. 79: 216-224.

WOODS C.E. 1971: Helminth parasites of fishes from the Forest River, North Dakota. Am. Midl. Nat. 86: 212-215.

YAMAGUTI S. 1975: A synoptical review of life histories of digenetic trematodes of vertebrates. Keigaku Publishing Co., 590 pp. +219 plates.

Accepted 20 July 2005 